\title{
Quick and effective improvement of leucine enriched dietary supplement on malnutrition in acute stroke patients receiving enteral tube feeding
}

\author{
Takahisa Mori* ${ }^{*}$ and Kazuhiro Yoshioka
}

\begin{abstract}
Background: Malnutrition often occurs in acute stroke patients receiving enteral tube feeding (ETF). Unless malnutrition is improved, their clinical outcome is poor. However, strategies to improve malnutrition in these patients have not been established. Branched-chain amino acids (BCAA) may enhance protein synthesis and attenuate inflammation. Our study aimed to investigate whether a leucine enriched BCAA dietary supplement (LEBDs) could quickly increase serum levels of albumin (Alb) or transthyretin (TTR) and decrease high-sensitivity Creactive protein (CRP) in the development of severe malnutrition within a few days after stroke onset compared to standard BCAA dietary supplement (SBDs).
\end{abstract}

Methods: We retrospectively included acute stroke patients who: 1) were admitted between August 2016 and July 2017; 2) underwent ETF for 7 days or longer after admission, and 3) underwent blood examination of Alb, TTR, and CRP on admission, the fifth day and the seventh day. We defined severe malnutrition as severe hypoproteinemia: decrease of TTR to less than $15 \mathrm{mg} / \mathrm{dl}$ on the 5th day. In LEBDs and SBDs groups, patients started to receive a dietary supplement containing leucine of 1.44 and $0.72 \mathrm{~g}$ twice a day on the fifth day, respectively. We evaluated Alb $(\mathrm{g} / \mathrm{dl})$, TTR $(\mathrm{mg} / \mathrm{dl})$, and CRP $(\mathrm{mg} / \mathrm{dl})$ on admission, the fifth day, and the seventh day.

Results: Twenty-nine patients met our inclusion criteria:15 in LEBDs and 14 in SBDs. In LEBDs and SBDs groups, the median Alb was 3.5 and $3.3 \mathrm{~g} / \mathrm{dl}$, TTR was 12.7 and $10.7 \mathrm{mg} / \mathrm{dl}$, and CRP was 1.02 and $0.673 \mathrm{mg} / \mathrm{dl}$ on admission, respectively. In LEBDs, the median Alb and TTR decreased to $2.6 \mathrm{~g} / \mathrm{dl}$ and $11.9 \mathrm{mg} / \mathrm{dl}$, and CRP increased to 5.337 $\mathrm{mg} / \mathrm{dl}$ on the fifth day. On the 7th day, TTR increased, and CRP decreased, although Alb did not improve. In SBDs, the median Alb and TTR decreased to $2.6 \mathrm{~g} / \mathrm{dl}$ and $9.7 \mathrm{mg} / \mathrm{dl}$, and CRP increased to $4.077 \mathrm{mg} / \mathrm{dl}$ on the fifth day. On the 7th day, Alb, TTR, and CRP did not improve.

Conclusion: In acute stroke patients receiving leucine enriched BCAA dietary supplement, quick improvements in transthyretin and CRP were observed.

Keywords: Severe stroke, Enteral tube feeding, Malnutrition, Transthyretin, Leucine, BCAA

\footnotetext{
*Correspondence: morit-koc@umin.net

Department of Stroke Treatment, Shonan Kamakura General Hospital Stroke

Center, Okamoto 1370-1, Kamakura City, Kanagawa 247-8533, Japan
}

C C The Author(s). 2020 Open Access This article is licensed under a Creative Commons Attribution 4.0 International License, which permits use, sharing, adaptation, distribution and reproduction in any medium or format, as long as you give appropriate credit to the original author(s) and the source, provide a link to the Creative Commons licence, and indicate if changes were made. The images or other third party material in this article are included in the article's Creative Commons licence, unless indicated otherwise in a credit line to the material. If material is not included in the article's Creative Commons licence and your intended use is not permitted by statutory regulation or exceeds the permitted use, you will need to obtain permission directly from the copyright holder. To view a copy of this licence, visit http://creativecommons.org/licenses/by/4.0/ The Creative Commons Public Domain Dedication waiver (http://creativecommons.org/publicdomain/zero/1.0/) applies to the data made available in this article, unless otherwise stated in a credit line to the data. 


\section{Background}

Malnutrition often occurs in severe acute stroke patients who are unable to take foods orally due to dysphagia or disturbed level of consciousness and who must receive enteral tube feeding (ETF) [1-3]. Malnutrition leads to the severity of the general condition and subsequently extended stay in hospital or in-hospital mortality [4-7]. Malnutrition may contribute to a weakened immune system and causes infection to occur [8]. Acute inflammation associated with infection exacerbates hypoproteinemia, and the clinical outcomes in patients with severe hypoproteinemia are generally poor. If malnutrition occurs in a patient, it should be treated and improved as soon as possible. Inflammation must be attenuated as soon as possible. However, it has not been established on how to improve hypoproteinemia rapidly [9]. Larger volumes of protein intake in the diet do not always lead to rapid improvement of hypoproteinemia and cessation of inflammation due to anabolic resistance in a severe clinical state $[10,11]$. Leucine is one of the essential amino acids and one of the branched-chain amino acids (BCAA) [12], and previous studies have reported that leucine enriched BCAA supplement may attenuate inflammation, enhance protein synthesis [13-15] and may be useful in recovering muscle mass and strength and in promoting rehabilitation [13, 16-19]. Our study aimed to investigate whether leucine-enriched BCAA dietary supplement (LEBDs) could quickly increase serum levels of albumin (Alb) or transthyretin (TTR) and quickly decrease high-sensitivity $C$-reactive protein $(C R P)$ in the development of severe malnutrition within a few days after stroke onset compared to standard BCAA dietary supplement (SBDs).

\section{Methods}

For the retrospective observational study, we included acute stroke patients who: 1) were admitted between August 2016 and July 2017, 2) started ETF on the second day and continued to undergo ETF for 7 days or longer after admission, 3) underwent blood examination on admission, the fifth day and the seventh day, and 4) started to receive LEBDs or SBDs to improve severe malnutrition on the fifth day. We defined severe malnutrition as rapid progression of hypoproteinemia: decrease of TTR to less than $15 \mathrm{mg} / \mathrm{dl}$, as TTR is a rapid turnover protein [20]. Patients started to receive LEBDs or SBDs twice a day on the fifth day added to baseline enteral nutrients.

\section{Exclusion criteria}

We excluded from our analysis patients who: 1) died due to very severe stroke within 7 days after its onset, 2) could take foods orally on admission, or 3) did not undergo a thorough blood examination.

\section{Target calories}

We calculated the target calories for patients according to the Harris-Benedict Equation (HBE) [21].

\section{Enteral nutrients}

We started to administer enteral nutrients on the second day of admission. Enteral nutrients (EN) we used to be IMPACT (Nestle Japan Co. Ltd.), PEPTAMEN AF (Nestle Japan Co. Ltd.), MEIN (Meiji Co. Ltd., Japan) or RENALEN MP (Meiji Co. Ltd., Japan). IMPACT includes contents that consist of protein of $14 \mathrm{~g}$ (arginineenhanced), containing leucine of $0.975 \mathrm{~g}$, lipid of $7.0 \mathrm{~g}$, containing middle-chain triglyceride (MCT) of $1.5 \mathrm{~g}$, and carbohydrates of $33.5 \mathrm{~g}$ against $250 \mathrm{kcal}$ per $250 \mathrm{ml}$ of one pack. PEPTAMEN AF includes contents that consist of protein of $19 \mathrm{~g}$, containing leucine of $2.03 \mathrm{~g}$ and whey peptide, lipid of $13.2 \mathrm{~g}$, containing MCT of $6.7 \mathrm{~g}$, and carbohydrates of $26.4 \mathrm{~g}$ against $300 \mathrm{kcal}$ per $200 \mathrm{ml}$ of one pack. MEIN consists of protein of $10 \mathrm{~g}$, containing leucine of $0.96 \mathrm{~g}$ and whey peptide, lipid of $5.6 \mathrm{~g}$, containing MCT of $1.2 \mathrm{~g}$, and carbohydrates of $29.8 \mathrm{~g}$, containing palatinose, against $200 \mathrm{kcal}$ per $200 \mathrm{ml}$ of one pack. Renalen MP consists of protein of $14 \mathrm{~g}$, containing leucine of $1.32 \mathrm{~g}$, lipid of $11.2 \mathrm{~g}$, containing MCT of 2.3 $\mathrm{g}$, and carbohydrates of $64.0 \mathrm{~g}$, containing palatinose, against $400 \mathrm{kcal}$ per $250 \mathrm{ml}$ of one pack. Palatinose is a disaccharide that consists of one glucose and one fructose, and it has a low glycemic index. Enteral nutrients except for RENALEN MP were protein-rich nutrients. Leucine enriched BCAA dietary supplement (LEBDs) (Leucine Plus, Nestle, and Ajinomoto, Japan) consists of protein of $8 \mathrm{~g}$, containing $1.44 \mathrm{~g}$ of leucine, and sugar of $18.5 \mathrm{~g}$, against $200 \mathrm{kcal}$ per $100 \mathrm{ml}$ of one pack, and standard BCAA dietary supplement (SBDs) (Meibalance Mini, Meiji Co. Ltd., Japan) consists of protein of $7.5 \mathrm{~g}$, containing leucine of $0.72 \mathrm{~g}$ and sugar of $29.3 \mathrm{~g}$, against $200 \mathrm{kcal}$ of one pack (Table 1). Protein volume in LEBDs was almost the same as in SBDs.

\section{Evaluation}

We evaluated patient features, TTR, Alb, and high-sensitivity CRP on admission, the fifth day, the 7th day, because previous studies have reported CRP elevation and decrease in Alb or TTR in patients with severe inflammation or severe acute conditions [22-24]. Besides, we evaluated Glasgow Coma Scale (GCS) [25], in-hospital clinical outcome, hospitalization days, and serum Cre on admission, the fifth day, the 7th day, because deterioration of renal function was a possible adverse effect of protein-rich EN.

\section{Statistical analysis}

Non-normally distributed continuous variables were expressed as the median and interquartile range (IQR). Differences between LEBDs and SBDs were compared 
Table 1 Contents of leucine enriched and standard BCAA dietary supplements

\begin{tabular}{lll}
\hline Dietary supplement & Leucine enriched BCAA & Standard BCAA \\
\hline Volume (1 pack) & $100 \mathrm{ml}$ & $125 \mathrm{ml}$ \\
Calories (1 pack) & $200 \mathrm{kcal}$ & $200 \mathrm{kcal}$ \\
Protein & $8.0 \mathrm{~g}$ & $7.5 \mathrm{~g}$ \\
BCAA & $2.07 \mathrm{~g}$ & 1.58 \\
$\quad$ Leucine & $\mathbf{1 . 4 4} \mathrm{g}$ & 0.72 \\
$\quad$ Valine & $0.36 \mathrm{~g}$ & 0.48 \\
Isoluecine & $0.27 \mathrm{~g}$ & 0.38 \\
Lipid & $10.3 \mathrm{~g}$ & $5.6 \mathrm{~g}$ \\
MCT & $3.3 \mathrm{~g}$ & no information \\
n-6 FA & $2.1 \mathrm{~g}$ & no information \\
n-3 FA & $0.3 \mathrm{~g}$ & no information \\
Carobohydrates & $20.4 \mathrm{~g}$ & $31.8 \mathrm{~g}$ \\
Sugar & $18.5 \mathrm{~g}$ & $29.3 \mathrm{~g}$ \\
Dietary fiber & $1.9 \mathrm{~g}$ & $2.5 \mathrm{~g}$ \\
Water & $70 \mathrm{~g}$ & $93.7 \mathrm{~g}$ \\
Na & $110 \mathrm{mg}$ & $110 \mathrm{mg}$ \\
K & $127 \mathrm{mg}$ & $120 \mathrm{mg}$ \\
\hline BCAABrathed & &
\end{tabular}

$B C A A$ Branched chain amino acid, kcal kcalorie, MCT Middle chain fatty acid, $F A$ Fatty acid, Na Natrium, $K$ Potassium

using a Fisher's exact test for categorical variables and a Wilcoxon rank-sum test for non-parametric data. For a comparison of paired variables, we used a Wilcoxon signed-rank test for non-parametric data. We performed a two-sided test for unpaired variables, a one-sided test for paired variables, and considered a probability of less than 0.05 statistically significant. We used the JMP (version 15.1) program to perform the statistical analysis.

\section{Results}

During the study period, we treated 800 acute stroke patients in our institution. Among patients who underwent ETF on the second day, the TTR level on the fifth day was less than $15 \mathrm{mg} / \mathrm{dl}$ in 29 patients, and the 15 patients started to receive LEBDs and the 14 patients started to receive SBDs on the 5th day. There were no differences in patients' characteristics between the two groups. Their median age was older than 80 years. In LEBDs and SBDs groups, the median GCS on admission was 9 and 9.5, respectively, and they suffered from impaired consciousness.

In LEBDs and SBDs groups, the median Alb was 3.5 and $3.3 \mathrm{~g} / \mathrm{dl}(\mathrm{ns})$, TTR was 12.7 and $10.7 \mathrm{mg} / \mathrm{dl}$ (ns), and CRP was 1.02 and $0.673 \mathrm{mg} / \mathrm{dl}$ (ns) on admission, respectively (Table 2). In LEBDs group, patients received baseline protein intake of $1.2(\mathrm{~g} / \mathrm{kg} /$ day) by enteral nutrition (Table 3). However, the median Alb decreased to $2.6 \mathrm{~g} / \mathrm{dl}(p<0.0001)$ and the median TTR decreased to
Table 2 Patients' characteristics in Leucine enriched and standard BCAA dietary supplements

\begin{tabular}{|c|c|c|c|}
\hline Dietary supplement & Leucine enriched & Standard BCAA & \\
\hline$n$ & 15 & 14 & $p$ \\
\hline Age, median (IQR) years & $82(77-92)$ & 80.5 (77.8-86.3) & ns \\
\hline Female (Sex), n (\%) & $9(60 \%)$ & $9(64.3 \%)$ & ns \\
\hline GCS, median (IQR) & $9(7-14)$ & $9.5(6.25-13)$ & ns \\
\hline BMI, median (IQR) & $21.8(17.6-23.5)$ & $19.8(16.4-22.9)$ & ns \\
\hline On admission & & & \\
\hline Alb, median (IQR) & $3.5(3-4.1)$ & $3.3(3-3.7)$ & ns \\
\hline TTR, median (IQR) & $12.7(12-17.2)$ & $10.7(8.25-13.0)$ & ns \\
\hline CRP, median (IQR) & $1.02(0.115-3.705)$ & $0.673(0.142-2.961)$ & ns \\
\hline Cre, median (IQR) & $0.78(0.71-1.04)$ & $0.695(0.51-0.91)$ & ns \\
\hline On the 5 th day & & & \\
\hline Alb, median (IQR) & $2.6(2.4-3.0)$ & $2.6(2.3-2.9)$ & ns \\
\hline TTR, median (IQR) & $11.8(7.3-12.6)$ & $9.65(7.83-11.9)$ & ns \\
\hline CRP, median (IQR) & $5.243(3.038-10.404)$ & $4.077(0.700-6.369)$ & ns \\
\hline Cre, median (IQR) & $0.74(0.65-2.06)$ & $0.63(0.50-0.88)$ & $<0.05$ \\
\hline On the 7th day & & & \\
\hline Alb, median (IQR) & $2.6(2.4-2.9)$ & $2.5(2.2-2.8)$ & ns \\
\hline TTR, median (IQR) & $15.7(10.2-20.2)$ & $10.7(8.3-12)$ & $<0.05$ \\
\hline CRP, median (IQR) & $4.774(1.183-6.563)$ & $2.459(0.921-5.656)$ & ns \\
\hline Cre, median (IQR) & $0.79(0.63-2.03)$ & $0.62(0.47-0.86)$ & ns \\
\hline $\begin{array}{l}\text { Enteral nutrient } \\
\text { (baseline) }\end{array}$ & & & \\
\hline Impact & 1 & 3 & \\
\hline Peptamen AF & 4 & 7 & \\
\hline Mein & 7 & 3 & \\
\hline Renalen MP & 3 & 1 & \\
\hline
\end{tabular}

$B C A A$ Branched chain amino acid, GCS Glasgow Coma Scale, BMI body mass index $\left(\mathrm{kg} / \mathrm{m}^{2}\right)$, Cre creatinine $(\mathrm{mg} / \mathrm{dl}), p$ probability, $\mathrm{ns}$ not significant

$11.9 \mathrm{mg} / \mathrm{dl}(p<0.001)$, and CRP increased to 5.337 $\mathrm{mg} / \mathrm{dl}(p<0.05)$ on the fifth day. We added the LEBDs $(2.88 \mathrm{~g}$ of leucine $/ 400 \mathrm{kcal} / 200 \mathrm{ml} /$ day) to baseline EN. On the 7th day, TTR increased $(p<0.001)$ and CRP decreased $(p<0.05)$ although Alb did not improve (Figs. 1, 2 and 3; left) (Table 4). In SBDs group, patients received baseline protein intake of 1.4 ( $\mathrm{g} / \mathrm{kg} /$ day) by enteral nutrition (Table 3 ). However, the median Alb decreased to $2.6 \mathrm{~g} / \mathrm{dl}(p<0.0001)$ and the median TTR decreased to $9.7 \mathrm{mg} / \mathrm{dl} \quad(p<0.05)$, and the median CRP increased to $4.077(p<0.05)$ on the fifth day. We added the SBDs (1.44 $\mathrm{g}$ of leucine/ $400 \mathrm{kcal} / 250 \mathrm{ml} /$ day) to baseline EN. On the 7 th day, Alb, TTR and CRP did not improve (Figs. 1, 2 and 3; right) (Table 4). The serum TTR level on the 7th day was higher in LEBDs than in SBDs, although there were no differences in TTR on the 5th day between LEBDs and SBDs (Table 2). 


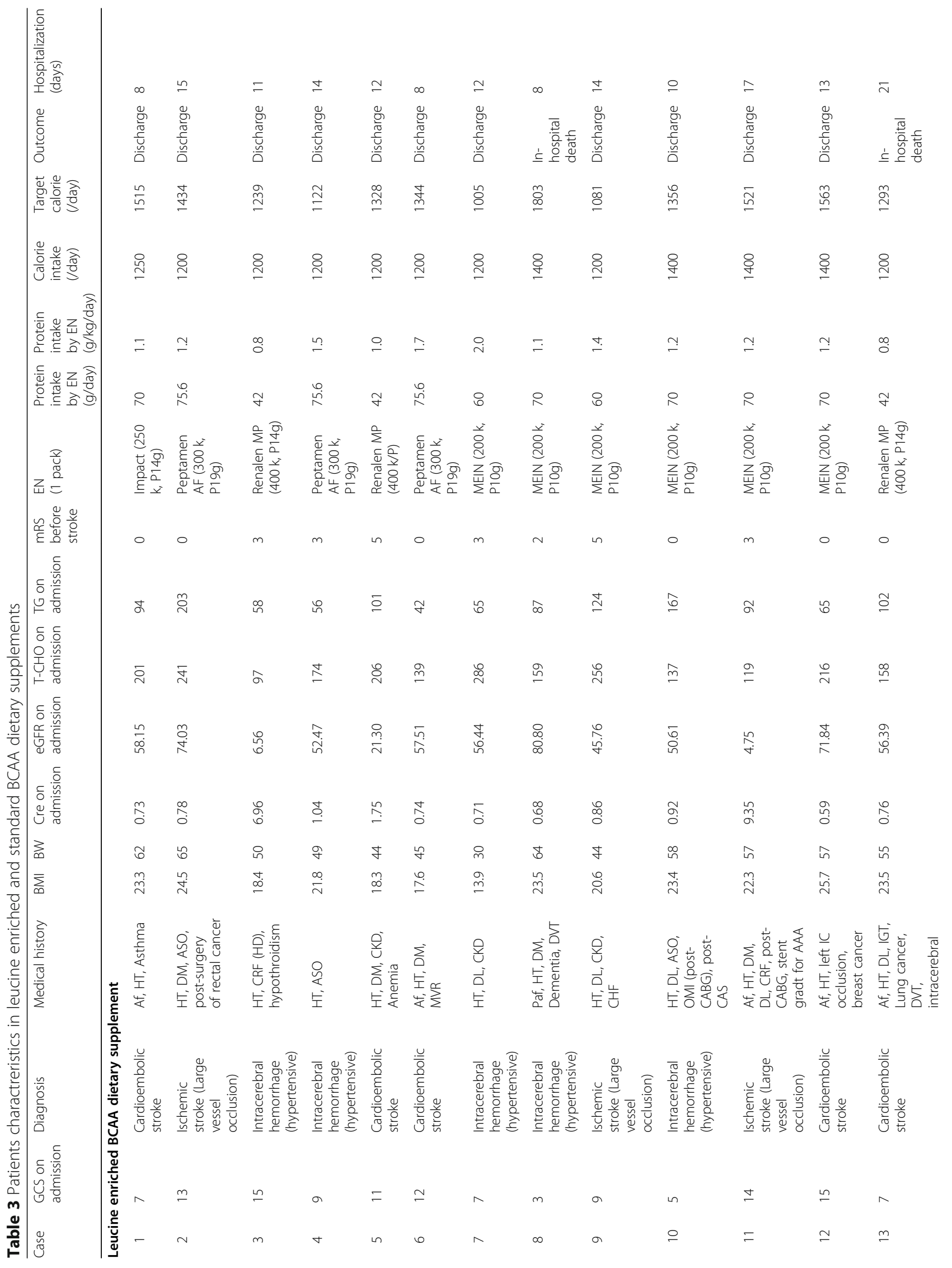




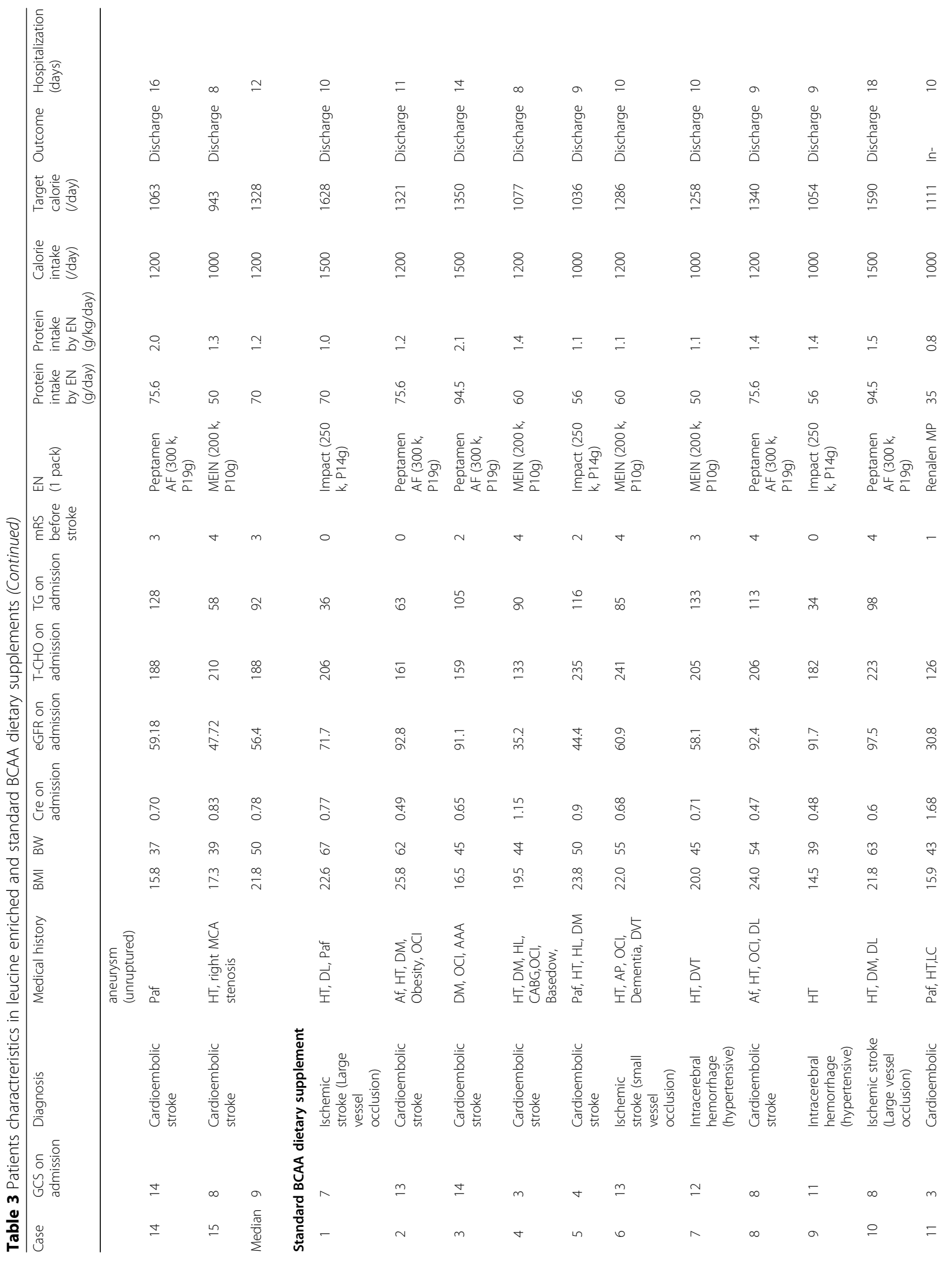




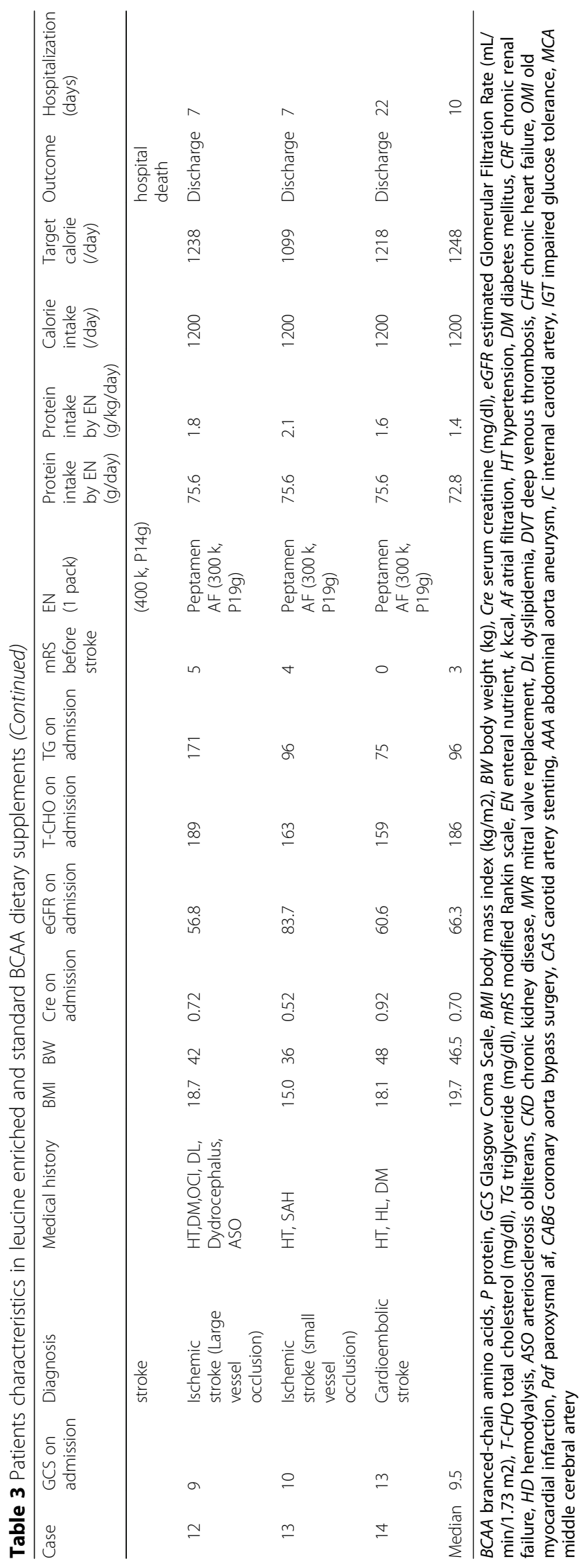



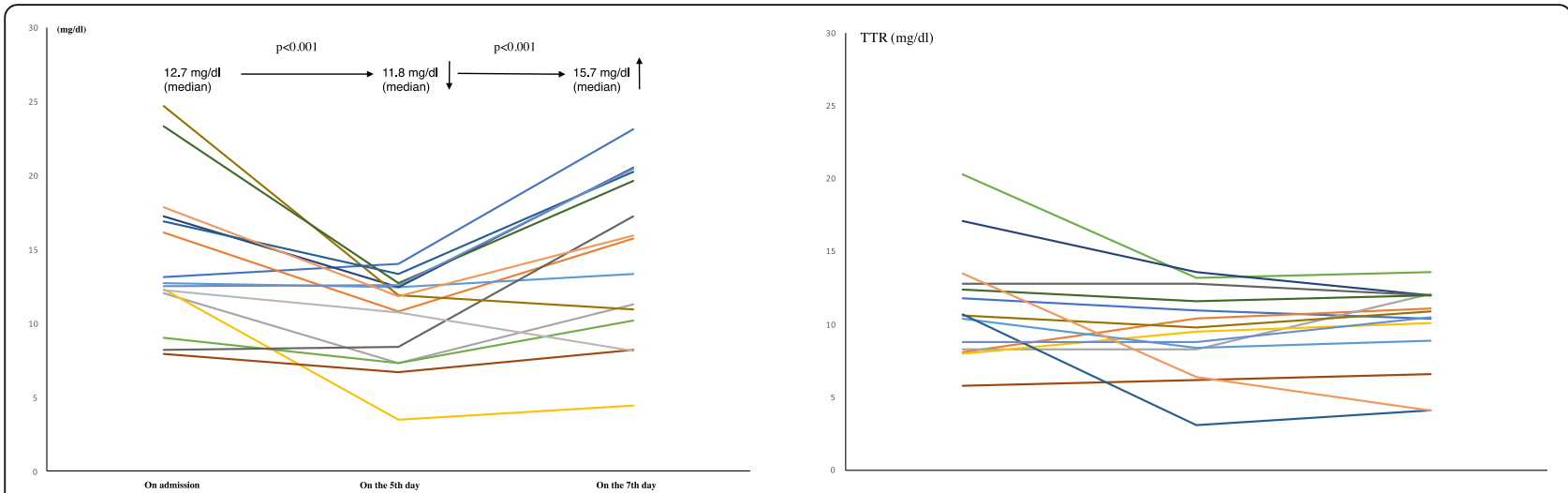

Fig. 1 Serial changes of serum TTR on admission, on the fifth day, and the seventh day. One-sided Wilcoxon signed-rank test was performed. Left: Leucine enriched BCAA dietary supplement, Right: Standard BCAA dietary supplement, BCAA: branched-chain amino acid, TTR: transthyretin

In LEBDs group, the median creatinine $(\mathrm{Cre})$ and estimated glomerular filtration rate (eGFR) on admission were $0.78(\mathrm{mg} / \mathrm{dl})$, and $56.4\left(\mathrm{~mL} / \mathrm{min} / 1.73 \mathrm{~m}^{2}\right)$, respectively. In 12 of the 15 patients, eGFR was less than $60(\mathrm{~mL} / \mathrm{min} / 1.73 \mathrm{~m} 2)$. The 12 patients suffered from renal dysfunction on admission (Table 3). In LEBDs group, the median target calorie and real calorie intake by EN was 1328 and $1200 \mathrm{kcal} /$ day, respectively. The calorie status was $90.4 \%$ of the plan on the fifth day. We used protein-rich EN except for REANALEN MP in 12 of the 15 patients (Table 3). In SBDs group, their median Cre and eGFR, on admission were $0.70(\mathrm{mg} / \mathrm{dl})$, and $66.3(\mathrm{~mL} / \mathrm{min} / 1.73$ $\mathrm{m} 2$ ). In 5 of the 14 patients, eGFR was less than 60 $\left(\mathrm{mL} / \mathrm{min} / 1.73 \mathrm{~m}^{2}\right)$. The 5 patients suffered from renal dysfunction on admission (Table 3). In SBDs group, the median target calorie and real calorie intake by EN was 1248 and $1200 \mathrm{kcal} /$ day, respectively. The calorie status was $96.2 \%$ of the plan on the fifth day. We used protein-rich EN except for REANALEN MP in 13 of the 14 patients (Table 3).

Overall renal function did not deteriorate except for two cases in LEBDs group (Table 4). In Case 2 and 4 in LEBDs group, serum Cre level acutely rose on the fifth day, and protein per day by PEPTAM EN AF was reduced from 75.6 to $56.7 \mathrm{~g}$ from the fifth day. The LEBDs was added on protein of 56.7 g by PEPTAMEN AF in case 2 and 4, and their Cre level did not deteriorate on the seventh day ( $\mathrm{Ta}$ bles 3 and 4).

In LEBDs, $13(86.7 \%)$ of the 15 patients discharged within 17 days, and they were transferred to comprehensive rehabilitation centers after their TTR and CRP were improving. Two of the 15 patients died on the eighth day and the twenty-first day, respectively. Median hospitalization in LEBDs was 12 days. In

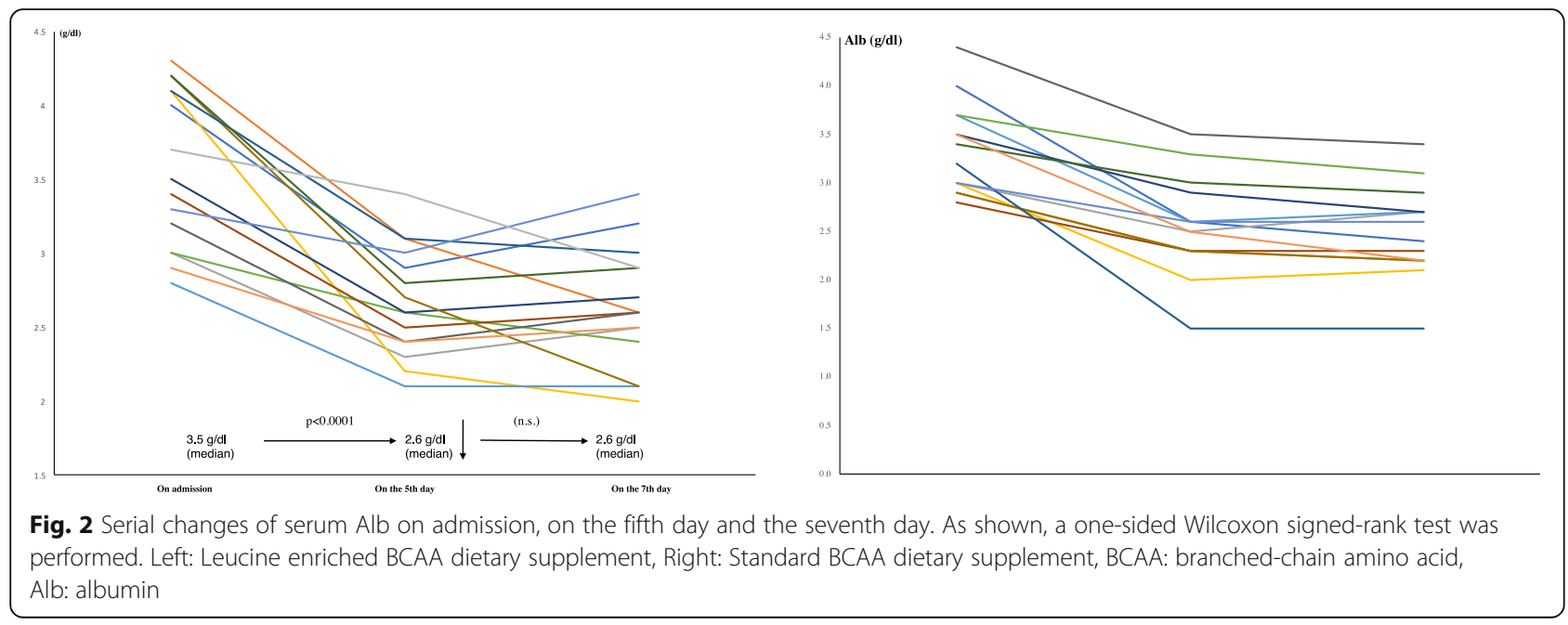



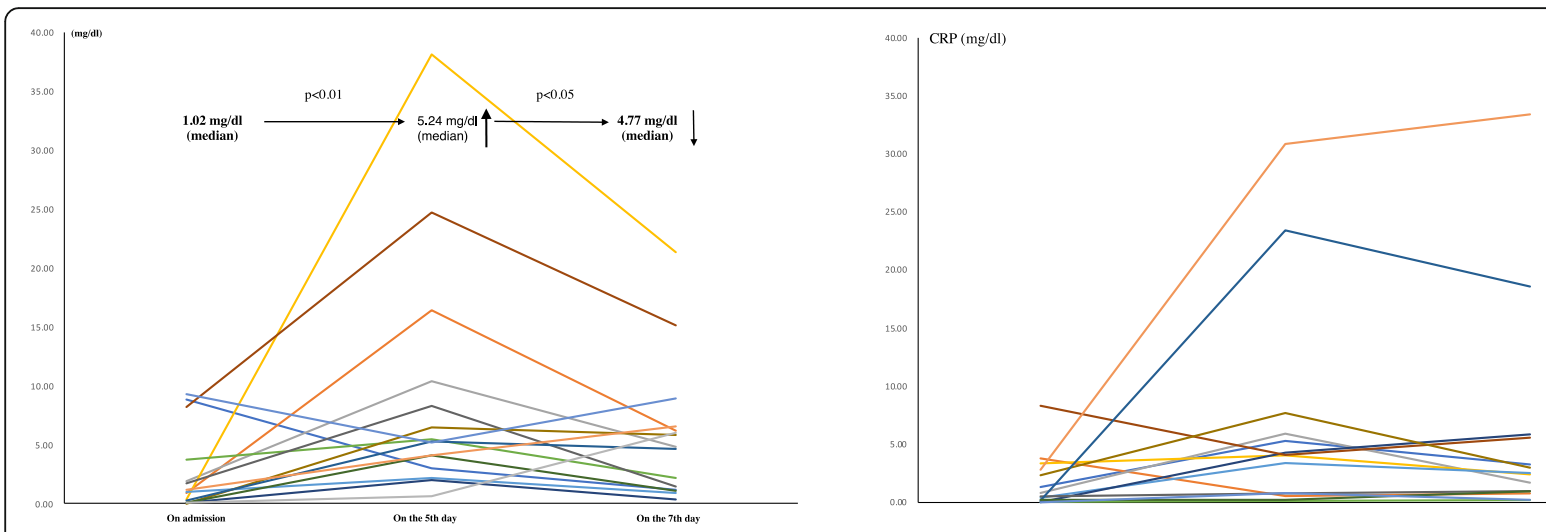

Fig. 3 Serial changes of serum CRP on admission, on the fifth day and the seventh day. One-sided Wilcoxon signed-rank test was performed. Left: Leucine enriched BCAA dietary supplement, Right: Standard BCAA dietary supplement, BCAA: branched-chain amino acid, CRP: highsensitivity C-reactive protein

SBDs, $12(85.7 \%)$ of the 14 patients discharged within 17 days, and they were transferred to comprehensive rehabilitation centers, although neither TTR nor CRP were not improving. One of the 14 patients died on the tenth day. Median hospitalization in SBDs was 10 days (Table 3 ).

\section{Discussion}

Our results demonstrate that quick improvements on the transthyretin and CRP level were observed in acute stroke patients who received leucine enriched BCAA dietary supplement added to baseline enteral nutrients.

Our patients were very elderly, suffered from impaired consciousness and renal dysfunction, and malnutrition within the 5 days of admission. We used EN containing leucine and MCT and provided protein of median $1.2 \mathrm{~g}$ or more $(/ \mathrm{kg} /$ day $)$ in the $29 \mathrm{pa}-$ tients [11]. Their TTR and Alb level, however, declined. Serum Cre acutely rose in two of the 25 patients administered with protein-rich EN, and protein-rich EN-induced deterioration of renal function, therefore, must be considered. We administered the LEBDs in the 15 patients, and 13 of them achieved an early discharge to comprehensive rehabilitation centers within 17 days after TTR and CRP were improving. Their clinical course was not usual. Thirteen of the 14 patients with SBDs survived and were transferred to comprehensive rehabilitation hospitals without improvements of TTR and CRP. SBDs might contribute to prevention of further deterioration of TTR, Alb and CRP, although SBDs could not improve them.
We supposed that the LEBDs had a quick effect on improvement of hypoproteinemia and cessation of inflammation in the 15 patients. After administration of the LEBDs, the TTR level rose soon, and the CRP level decreased soon, probably because leucine enriched BCAA played critical roles in the regulation of energy homeostasis, nutrition metabolism, gut health, immunity as they acted as potential antiinflammatory mediators [26-28], further helped attenuate inflammation and enhance protein synthesis $[13,27,28]$. The Alb level did not change soon after the administration of the LEBDs, as the Alb level usually improves slowly. The LEBDs likely provides benefits with malnutrition patients in a stroke care unit or intensive care unit.

\section{Study limitations}

Our study had several limitations. Our study included a small number of patients. Our study was not a prospective randomized controlled study but a retrospective observational cohort study of routine medical care. We, therefore, did not have a placebo-controlled group without BCAA supplement, and we compared LEBDs group with SBDs group. The LEBDs contained MCT or n-3 fatty acids; no information, however, was provided in SBDs. Our patients started to use different types of enteral nutrients as the baseline. All patients were likely of Japanese ancestry; therefore, not representative of the general population. Our study investigated short-term outcomes of blood examinations, in-hospital death, and hospitalization days but did not study the long-term effect. To confirm our results, 
Table 4 Changes of serum markers in leucine enriched and standard BCAA dietary supplements

\begin{tabular}{|c|c|c|c|c|c|c|c|c|c|c|c|c|}
\hline Case & $\begin{array}{l}\text { TTR on } \\
\text { admission }\end{array}$ & $\begin{array}{l}\text { TTR on } \\
\text { the fifth } \\
\text { day }\end{array}$ & $\begin{array}{l}\text { TTR on } \\
\text { the seventh } \\
\text { day }\end{array}$ & $\begin{array}{l}\text { Alb on } \\
\text { admission }\end{array}$ & $\begin{array}{l}\text { Alb on } \\
\text { the fifth } \\
\text { day }\end{array}$ & $\begin{array}{l}\text { Alb on the } \\
\text { seventh day }\end{array}$ & $\begin{array}{l}\text { CRP on } \\
\text { admission }\end{array}$ & $\begin{array}{l}\text { CRP on } \\
\text { the fifth } \\
\text { day }\end{array}$ & $\begin{array}{l}\text { CRP on } \\
\text { the seventh } \\
\text { day }\end{array}$ & $\begin{array}{l}\text { Cre on } \\
\text { admission }\end{array}$ & $\begin{array}{l}\text { Cre on } \\
\text { the fifth } \\
\text { day }\end{array}$ & $\begin{array}{l}\text { Cre on the } \\
\text { seventh day }\end{array}$ \\
\hline \multicolumn{13}{|c|}{ Leucine enriched BCAA dietary supplement } \\
\hline 1 & 13.1 & 14.0 & 23.1 & 4.0 & 2.9 & 3.2 & 8.831 & 3.038 & 1.183 & 0.73 & 0.53 & 0.52 \\
\hline 2 & 16.1 & 10.8 & 15.7 & 4.3 & 3.1 & 2.6 & 0.870 & 16.376 & 6.161 & 0.78 & 1.25 & 1.16 \\
\hline 3 & 12.0 & 7.3 & 11.3 & 3.0 & 2.3 & 2.5 & 1.862 & 10.404 & 4.774 & 6.96 & 5.67 & 5.79 \\
\hline 4 & 12.3 & 3.5 & 4.4 & 4.1 & 2.2 & 2.0 & 0.324 & 38.079 & 21.280 & 1.04 & 3.97 & 2.03 \\
\hline 5 & 12.7 & 12.4 & 13.3 & 2.8 & 2.1 & 2.1 & 1.020 & 2.160 & 0.941 & 1.75 & 2.06 & 1.83 \\
\hline 6 & 9.0 & 7.3 & 10.2 & 3.0 & 2.6 & 2.4 & 3.705 & 5.431 & 2.131 & 0.74 & 0.74 & 0.79 \\
\hline 7 & 17.2 & 12.4 & 20.5 & 3.5 & 2.6 & 2.7 & 0.036 & 2.009 & 0.385 & 0.71 & 0.69 & 0.62 \\
\hline 8 & 7.9 & 6.7 & 8.2 & 3.4 & 2.5 & 2.6 & 8.168 & 24.719 & 15.136 & 0.68 & 0.92 & 2.09 \\
\hline 9 & 8.2 & 8.4 & 17.2 & 3.2 & 2.4 & 2.6 & 1.673 & 8.285 & 1.457 & 0.86 & 0.70 & 0.65 \\
\hline 10 & 24.7 & 11.9 & 10.9 & 4.2 & 2.7 & 2.1 & 0.016 & 6.469 & 5.849 & 0.92 & 1.01 & 0.82 \\
\hline 11 & 16.9 & 13.3 & 20.2 & 4.1 & 3.1 & 3.0 & 0.273 & 5.243 & 4.605 & 9.35 & 4.74 & 5.34 \\
\hline 12 & 23.3 & 12.7 & 19.6 & 4.2 & 2.8 & 2.9 & 0.093 & 4.078 & 1.045 & 0.59 & 0.54 & 0.63 \\
\hline 13 & 12.5 & 12.6 & 20.4 & 3.3 & 3.0 & 3.4 & 9.265 & 5.199 & 8.887 & 0.76 & 0.56 & 0.64 \\
\hline 14 & 17.8 & 11.8 & 15.9 & 2.9 & 2.4 & 2.5 & 1.212 & 4.066 & 6.563 & 0.70 & 0.65 & 0.50 \\
\hline 15 & 12.2 & 10.7 & 8.1 & 3.7 & 3.4 & 2.9 & 0.115 & 0.598 & 6.046 & 0.83 & 0.70 & 0.64 \\
\hline Median & 12.9 & 11.9 & 15.8 & 3.5 & 2.6 & 2.6 & 1.116 & 5.337 & 4.690 & 0.77 & 0.83 & 0.81 \\
\hline $\begin{array}{l}\text { MDB } \\
A-5\end{array}$ & & $\begin{array}{l}-3.6 \\
(p<0.001)\end{array}$ & & & $\begin{array}{l}-0.9 \\
(p<0.0001)\end{array}$ & & & $\begin{array}{l}4.0 \\
(p<0.01)\end{array}$ & & & -0.05 (ns) & \\
\hline $\begin{array}{l}\text { MDB } \\
5-7\end{array}$ & & & $\begin{array}{l}4.1 \\
(p<0.001)\end{array}$ & & & 0.1 (ns) & & & $\begin{array}{l}-1.9 \\
(p<0.05)\end{array}$ & & & -0.05 (ns) \\
\hline
\end{tabular}

\section{Standard BCAA dietary supplement}

\begin{tabular}{|c|c|c|c|c|c|c|c|c|c|c|c|c|}
\hline 1 & 11.8 & 11.0 & 10.4 & 4.0 & 2.6 & 2.4 & 1.332 & 5.301 & 3.268 & 0.77 & 0.72 & 0.70 \\
\hline 2 & 8.1 & 10.4 & 11.1 & 2.9 & 2.3 & 2.2 & 3.796 & 0.555 & 0.791 & 0.49 & 0.54 & 0.65 \\
\hline 3 & 8.3 & 8.3 & 12.1 & 3.0 & 2.5 & 2.7 & 0.822 & 5.924 & 1.721 & 0.65 & 0.51 & 0.51 \\
\hline 4 & 8.0 & 9.5 & 10.1 & 3.0 & 2.0 & 2.1 & 3.388 & 4.058 & 2.419 & 1.15 & 1.10 & 1.08 \\
\hline 5 & 10.4 & 8.4 & 8.9 & 3.7 & 2.6 & 2.7 & 0.407 & 3.396 & 2.499 & 0.9 & 0.85 & 0.87 \\
\hline 6 & 20.3 & 13.2 & 13.6 & 3.7 & 3.3 & 3.1 & 0.050 & 0.149 & 0.210 & 0.68 & 0.63 & 0.64 \\
\hline 7 & 17.1 & 13.6 & 12.0 & 3.5 & 2.9 & 2.7 & 0.028 & 4.327 & 5.864 & 0.71 & 0.62 & 0.60 \\
\hline 8 & 5.8 & 6.2 & 6.6 & 2.8 & 2.3 & 2.3 & 8.327 & 4.095 & 5.587 & 0.47 & 0.41 & 0.42 \\
\hline 9 & 12.8 & 12.8 & 12.0 & 4.4 & 3.5 & 3.4 & 0.524 & 0.748 & 0.984 & 0.48 & 0.45 & 0.40 \\
\hline 10 & 10.6 & 9.8 & 10.9 & 2.9 & 2.3 & 2.2 & 2.345 & 7.703 & 3.041 & 0.60 & 0.40 & 0.39 \\
\hline 11 & 10.7 & 3.1 & 4.1 & 3.2 & 1.5 & 1.5 & 0.172 & 23.428 & 18.559 & 1.68 & 1.61 & 1.85 \\
\hline 12 & 12.4 & 11.6 & 12.0 & 3.4 & 3.0 & 2.9 & 0.227 & 0.227 & 0.964 & 0.72 & 0.64 & 0.57 \\
\hline 13 & 8.8 & 8.8 & 10.5 & 3.0 & 2.6 & 2.6 & 0.015 & 0.812 & 0.196 & 0.52 & 0.52 & 0.48 \\
\hline 14 & 13.5 & 6.4 & 4.1 & 3.5 & 2.5 & 2.2 & 2.819 & 30.905 & 33.414 & 0.92 & 0.97 & 0.85 \\
\hline Median & 10.7 & 9.7 & 10.7 & 3.3 & 2.6 & 2.5 & 0.673 & 4.077 & 2.459 & 0.70 & 0.63 & 0.62 \\
\hline $\begin{array}{l}\text { MDB } \\
A-5\end{array}$ & & $\begin{array}{l}-0.8 \\
(<0.05)\end{array}$ & & & $\begin{array}{l}-0.6 \\
(p<0.0001)\end{array}$ & & & $\begin{array}{l}1.893 \\
(p<0.05)\end{array}$ & & & $\begin{array}{l}-0.015 \\
(p<0.01)\end{array}$ & \\
\hline $\begin{array}{l}\mathrm{MDB} \\
5-7\end{array}$ & & & 0.45 (ns) & & & -0.1 (ns) & & & -0.278 (ns) & & & -0.05 (ns) \\
\hline
\end{tabular}

$B C A A$ branched-chain amino acids, TTR transthretin (mg/dl), Alb albumin (g/dl), CRP high-sensitivity C-reactive protein (mg/dl), Cre creatinine (mg/dl), $M D B A-5$ median difference between on admission and the fifth day, MDB 5-7 median difference between on the fifth and the seventh day, $p$ probability, ns not significant 
therefore, future prospective studies are required in patients with the standardization of enteral nutrients.

\section{Conclusion}

In acute stroke patients receiving leucine enriched BCAA dietary supplement, quick improvements in transthyretin and CRP were observed compared to patients with standard BCAA dietary supplement. The results warrant the further clinical application of the LEBDs in acute patients with malnutrition.

\section{Abbreviations}

Alb: Albumin; BCAA: Branched-chain amino acid; BMI: Body mass index; BW: Body weight; Cre: Creatinine; CRP: C-reactive protein; eGFR: estimated glomerular filtration rate; EN: Enteral nutrient; ETF: Enteral tube feeding; LEBDs: Leucine enriched BCAA dietary supplement; SBDs: Standard BCAA dietary supplement; TTR: Transthyretin

\section{Acknowledgments}

We would like to thank Nozomi Chiba, B.A., for her secretarial assistance, and the specialized assistance of the nurses and the nutritionists at our comprehensive stroke center.

\section{Authors' contributions}

Full access to all data in the study and responsibility for the integrity of the data and accuracy of the data analysis: TM. Study concept and design: TM. Patient treatment and care: TM, KY. Acquisition of data: TM, KY. Interpretation of data and statistical analysis: TM. Drafting the manuscript: TM. Critical revision of the manuscript for relevant intellectual content: TM. Final approval of the submitted version: TM, KY.

\section{Funding}

The authors received no specific funding for this work.

\section{Availability of data and materials}

The datasets analyzed during the current study are available from the corresponding author on reasonable request.

\section{Ethics approval and consent to participate}

All procedures performed in the study were in accordance with the ethical standards of the institution (Shonan Kamakura General Hospital) and with the 1964 Helsinki Declaration. The Tokushukai Group Ethical Committee approved access to medical records for our retrospective analysis. Informed consent was not required because of routine medical care, the retrospective access to medical records in very elderly, disabled stroke patients treated four years ago, and the anonymization of patient identifiers.

\section{Consent for publication}

Not applicable.

\section{Competing interests}

The authors have no conflicts of interest to disclose.

Received: 19 March 2020 Accepted: 6 July 2020

Published online: 20 July 2020

\section{References}

1. Ignacio de Ulibarri J, Gonzalez-Madrono A, de Villar NG, Gonzalez P Gonzalez B, Mancha A, et al. CONUT: a tool for controlling nutritional status. First validation in a hospital population. Nutrition Hospitalaria. 2005;20:38-45.

2. Fukushima K, Ueno Y, Kawagishi N, Kondo Y, Inoue J, Kakazu E, et al. The nutritional index 'CONUT' is useful for predicting long-term prognosis of patients with end-stage liver diseases. Tohoku J Exp Med. 2011;224:215-9.

3. Zhang SQ, Peng B, Stary CM, Jian ZH, Xiong XX, Chen QX. Serum prealbumin as an effective prognostic indicator for determining clinical status and prognosis in patients with hemorrhagic stroke. Neural Regen Res. 2017;12:1097-102
4. Kamijo Y, Kanda E, Ishibashi Y, Yoshida M. Sarcopenia and frailty in PD: impact on mortality, malnutrition, and inflammation. Perit Dial Int. 2018;38: 447-54.

5. Izaola O, Gomez Hoyos E, Lopez JJ, Ortola A, Torres B, Primo D, et al. The 10-item eating assessment tool is associated with nutritional status, mortality and hospital stay in elderly individuals requiring hospitalization with acute diseases. Nutrition Hospitalaria. 2018;35:827-32.

6. Isono N, Imamura Y, Ohmura K, Ueda N, Kawabata S, Furuse M, et al. Transthyretin concentrations in acute stroke patients predict convalescent rehabilitation. J Stroke Cerebrovasc Dis. 2017;26:1375-82.

7. Gao C, Zhang B, Zhang W, Pu S, Yin J, Gao Q. Serum prealbumin (transthyretin) predict good outcome in young patients with cerebral infarction. Clin Exp Med. 2011:11:49-54.

8. Bourke CD, Berkley JA, Prendergast AJ. Immune dysfunction as a cause and consequence of malnutrition. Trends Immunol. 2016:37:386-98.

9. Pellicane AJ, Millis SR, Barker KD, Temme KE, Sayyad A, Oswald MC, et al. The effect of protein and calorie intake on prealbumin, complications, length of stay, and function in the acute rehabilitation inpatient with stroke. NeuroRehabilitation. 2013:33:367-76.

10. Mercier S, Breuille D, Mosoni L, Obled C, Patureau MP. Chronic inflammation alters protein metabolism in several organs of adult rats. J Nutr. 2002;132: 1921-8.

11. Morton RW, Traylor D, Weijs P, Phillips S. Defining anabolic resistance: implications for delivery of clinical care nutrition. Curr Opin Crit Care. 2018; 24:124-30.

12. Zhang S, Zeng X, Ren M, Mao X, Qiao S. Novel metabolic and physiological functions of branched chain amino acids: a review. J Animal Sci Biotechnol. 2017:8:10.

13. Kato H, Miura K, Nakano S, Suzuki K, Bannai M, Inoue Y. Leucine-enriched essential amino acids attenuate inflammation in rat muscle and enhance muscle repair after eccentric contraction. Amino Acids. 2016;48:2145-55.

14. Mori T, Tanno Y, Kasakura S, Yoshioka K, Nakai N, Oonuma Y. Impact of Leucine, Branched Chain Amino Acid, on Treating Malnutrition (O-026-6). In: The 43rd annual meeting of the Japan Stroke Society; 2018. March in Fukuoka.

15. Oonuma Y, Tanno Y, Chiba N, Mori T. Rapid improvement of malnutrition following treatment by leucine- enhanced branched chain amino acid in severe acute stroke patients fed with enteral nutrition. Stroke. 2019:50: ATP481.

16. Kato $H$, Suzuki $H$, Mimura $M$, Inoue $Y$, Sugita $M$, Suzuki $K$, et al. Leucineenriched essential amino acids attenuate muscle soreness and improve muscle protein synthesis after eccentric contractions in rats. Amino Acids. 2015;47:1193-201

17. Bukhari SS, Phillips BE, Wilkinson DJ, Limb MC, Rankin D, Mitchell WK, et al. Intake of low-dose leucine-rich essential amino acids stimulates muscle anabolism equivalently to bolus whey protein in older women at rest and after exercise. Am J Physiol Endocrinol Metab. 2015:308:E1056-65.

18. Scherbakov N, Ebner N, Sandek A, Meisel A, Haeusler KG, von Haehling S, et al. Influence of essential amino acids on muscle mass and muscle strength in patients with cerebral stroke during early rehabilitation: protocol and rationale of a randomized clinical trial (AMINO-stroke study). BMC Neurol. 2016;16:10

19. Yoshimura $Y$, Bise $T$, Shimazu S, Tanoue M, Tomioka $Y$, Araki M, et al. Effects of a leucine-enriched amino acid supplement on muscle mass, muscle strength, and physical function in post-stroke patients with sarcopenia: a randomized controlled trial. Nutrition. 2019;58:1-6.

20. Kudo D, Miyakoshi N, Hongo M, Kasukawa Y, Ishikawa Y, Mizutani T, et al. Relationship between preoperative serum rapid turnover proteins and early-stage surgical wound infection after spine surgery. Eur Spine J. 2017;26:3156-61.

21. Long CL, Schaffel N, Geiger JW, Schiller WR, Blakemore WS. Metabolic response to injury and illness: estimation of energy and protein needs from indirect calorimetry and nitrogen balance. JPEN J Parenter Enteral Nutr. 1979;3:452-6

22. Ferard G, Gaudias J, Bourguignat A, Ingenbleek Y. C-reactive protein to transthyretin ratio for the early diagnosis and follow-up of postoperative infection. Clin Chem Lab Med. 2002:40:1334-8.

23. Yang HT, Yim H, Cho YS, Kim D, Hur J, Kim JH, et al. Serum transthyretin level is associated with clinical severity rather than nutrition status in massively burned patients. JPEN J Parenter Enteral Nutr. 2014;38:966-72.

24. Tsuboi A Terazawa-Watanabe M, Kazumi T, Fukuo K. Associations of decreased serum transthyretin with elevated high-sensitivity CRP, serum 
copper and decreased hemoglobin in ambulatory elderly women. Asia Pac J Clin Nutr. 2015;24:83-9.

25. Teasdale G, Jennett B. Assessment of coma and impaired consciousness: a practical scale. Lancet. 1974;304:81-4.

26. Nie C, He T, Zhang W, Zhang G, Ma X. Branched chain amino acids: beyond nutrition metabolism. Int J Mol Sci. 2018;19:1-16.

27. Nicastro $\mathrm{H}$. Are the BCAAs/leucine supplementation effects on exerciseinduced muscle damage related to HMB? J Nutr Health Food Sci. 2014;2:1-3.

28. Nicastro H, da Luz CR, Chaves DF, Bechara LR, Voltarelli VA, Rogero MM, et al. Does branched-chain amino acids supplementation modulate skeletal muscle remodeling through inflammation modulation? Possible mechanisms of action. J Nutr Metab. 2012;2012:1-10.

\section{Publisher's Note}

Springer Nature remains neutral with regard to jurisdictional claims in published maps and institutional affiliations.

Ready to submit your research? Choose BMC and benefit from:

- fast, convenient online submission

- thorough peer review by experienced researchers in your field

- rapid publication on acceptance

- support for research data, including large and complex data types

- gold Open Access which fosters wider collaboration and increased citations

- maximum visibility for your research: over $100 \mathrm{M}$ website views per year

At BMC, research is always in progress.

Learn more biomedcentral.com/submissions 